\title{
ANALISIS PENDAPATAN DAN KELAYAKAN USAHA KOPRA
}

\author{
Nurwahida $^{1)}$, Marhawati' ${ }^{2}$, Mustari ${ }^{3)}$, Rahmatullah $^{4)}$, Nurdiana $^{5)}$ \\ Universitas Negeri Makassar ${ }^{1}$ \\ Email: nurwahidaa15@gmail.com ${ }^{1}$
}

\begin{abstract}
ABSTRAK
Penelitian ini bertujuan untuk mengetahui pendapatan usahatani kopra dan besarnya R/C rasio kopra per satu kali produksi di Desa Bontolempangan Kecamatan Buki Kabupaten Kepulauan Selayar. Responden dalam Penelitian ini sebanyak 24 orang. Penarikan sampel menggunakan simple Random Sampling dengan teknik pengumpulan data yang dilakukan adalah observasi, wawancara, dan dokumentasi. Teknik analisis data yang dilakukan yaitu analisis pendapatan, $\mathrm{R} / \mathrm{C}$ rasio, dan analisis Break Even Point (BEP). Hasil penelitian menunjukkan: pendapatan rata-rata usahatani kopra di Desa Bontolempangan Kecamatan Buki Kabupaten Kepulauan Selayar dalam satu kali produksi sebesar Rp. 1.036.333, R/C rasio yang diperoleh yaitu sebesar 1,3, BEP terjadi pada tingkat produksi $24 \mathrm{Kg}$ dan harga Rp. 135.000 yang berarti petani tersebut mengalami keuntungan. Dengan demikian maka Usahatani kopra yang dilakukan oleh petani di Desa Bontolempangan Kecamatan Buki Kabupaten Kepulauan Selayar layak untuk diusahakan oleh para petani.
\end{abstract}

Kata Kunci: Analisis Usahatani Kopra, Pendapatan, Break Even Point

\begin{abstract}
ABTRACT
This resesrch aims to determine the income of copra farming and the amount of R / C ratio of copra per one production time in Bontolempangan Village, Buki District, Selayar Islands Regency. Respondents in this study were 24 people. Sampling using simple random sampling with data collection techniques used are observation, interviews, and documentation. The data analysis techniques used are income analysis techniques, R / C ratio analysis, and Break Even Point (BEP) analysis. The results showed: the average income of copra farming in Bontolempangan Village, Buki District, Selayar Islands Regency in one production season is Rp. 1.036.333, the $\mathrm{R} / \mathrm{C}$ ratio obtained is 1.3 , occurs at a production level of $24 \mathrm{~kg}$ and a price of $\mathrm{Rp} .135,000$ which means that the farmer experiences a profit. Thus, copra farming carried out by farmers in Bontolempangan Village, Buki District, Selayar Islands Regency is feasible to be cultivated by farmers.
\end{abstract}

Keywords: Copra Farming analysis, income, Break Even Point. 


\section{PENDAHULUAN}

Tanaman kelapa merupakan tanaman asli daerah tropis dan dapat ditemukan diseluruh wilayah Indonesia, mulai dari daerah pesisir pantai hingga daerah pegunungan yang agak tinggi. Bagi rakyat Indonesia tanaman kelapa merupakan salah satu komoditas penting setelah padi. Tanaman kelapa di Indonesia sebagian besar diusahakan sebagai perkebunan rakyat yang tersebar di seluruh pelosok nusantara (Negosino, 2013). Kelapa (Cocos nucifera L) memiliki peran strategis bagi masyarakat Indonesia, bahkan termasuk komoditi sosial, mengingat produknya merupakan salah satu dari sembilan bahan pokok masyarakat. Peran strategis itu terlihat dari total luas perkebunan kelapa di Indonesia yang mencapai 3.712 juta hektar (31.4\%) dan merupakan luas areal perkebunan kelapa terbesar didunia. Produksi kelapa di Indonesia menempati urutan kedua didunia yakni sebesar 12.915 milyar butir (24.4\% produksi dunia) (Alamsyah, 2005). Hal inilah yang membuat Indonesia merupakan Negara produsen kelapa terbesar di dunia, bersaing dengan Negara Filipina dan India. Ekspor kelapa Indonesia dari tahun ke tahun terus meningkat (Soundakh dkk)

Menurut data tiga tahun terakhir (2016-2018) luas areal perkebunan kelapa dan produksi dalam wujud kopra secara nasional mengalami penurunan. Luas areal perkebunan kelapa Indonesia pada tahun 2016 tercatat pada tahun 2016 tercatat pada angka 3.617.564 ha dengan produksi sebesar 2.904.170 ton. Sedangkan pada tahun 2017, luas areal perkebunan kelapa Indonesia adalah 3.617.007 ha dengan jumlah produksi sebanyak 2.870.739 ton. Serta pada tahun 2018 dimana jumlah areal perkebunan kelapa Indonesia diestimasikan menyentuh pada angka 3.613.486 ha dengan tingkat produksi sebesar 2.865.870 ton (Ditjenbun, 2018).

Sulawesi Selatan merupakan salah satu provinsi produsen tumbuhan kelapa di Indonesia. Berdasarkan data estimasi statistik terbaru yang dikeluarkan oleh Kementerian Pertanian pada tahun 2018, Sulawesi Selatan menempati peringkat ke 13 dalam hal luas areal perkebunan kelapa sebesar 75.015 ha. Sedangkan untuk tingkat produksi dalam wujud kopra, Sulawesi Selatan menempati urutan ke 16 dengan nilai 69.023 ton. Untuk tingkat kabupaten, Selayar dan kepulauan menjadi kabupaten terbanyak penyumbang produksi tumbuhan kelapa. Rata-rata produksi kelapa Selayar hingga 20.000 ton/tahun dengan luas areal perkebunan sebesar 18.341,57 ha, unggul jauh dibanding Kabupaten lain seperti Kabupaten Bone dengan jumlah 11.000 ton/tahun atau Kabupaten Pinrang sebanyak 4.000 ton/tahun (Ditjenbun 2018). Untuk meningkatkan nilai ekonomis kelapa, para petani di Selayar mengolah kelapa menjadi kopra.

Kopra merupakan salah satu hasil olahan daging buah kelapa yang banyak diusahakan oleh masyarakat karena prosesnya sangat sederhana. Biaya produksinya relatif rendah jika dibanding pengolahan daging kelapa menjadi produk santan kering atau minyak goreng. Kopra banyak diusahakan oleh masyarakat di Selayar, komoditas ini telah memberikan kontribusi yang cukup besar terhadap peningkatan perekonomian. Selain menjadi sumber devisa, juga merupakan komoditas unggulan yang sangat menjanjikan serta menjadi tumpuan harapan masa depan bagi sebagian masyarakat di 
Kepulauan Selayar. Usaha kopra merupakan salah satu mata pencaharian bagi masyarakat Desa Bontolempangan Kecamatan Buki Kabupaten Kepulauan Selayar.

Untuk mengetahui tingkat kesejahteraan petani kopra, maka kita dapat melihat dari tingkat pendapatannya. Pendapatan adalah uang yang diterima oleh seseorang dan perusahaan dalam bentuk gaji, upah, sewa, bunga, dan laba, termasuk juga beragam tunjangan seperti kesehatan dan pensiun (Wulandari,2019). Pendapatan seseorang pada dasarnya tergantung dari pekerjaan dibidang jasa atau produksi, serta waktu jam kerja yang dicurahkan, tingkat pendapatan per jam yang diterima (Pangandaheng, 2012). Perluh diketahui bahwa pendapatan usahatani mempunyai defenisi yang berbeda dengan pendapatan yang umumnya bersifat nominal. Pendapatan usahatani dipengaruhi oleh faktor luas usaha, tingkat produksi, pilihan dan kombinasi, intensitas pertanaman, dan efisiensi tenaga kerja. Hal inilah yang mempengaruhi daya beli masyarakat terhadap barang yang disesuaikan dengan pendapatan nominalnya. Sehingga menyebabkan pendapatan usahatani fluktuatif (Uswa, 2017). Pendapatan akan didapatkan jika usahatani telah melewati titik impas. Terkadang para usahatani melupakan hal tersebut. Rendahnya kemampuan manajemen dan keterampilan dalam menerapkan teknologi sangat besar peranannya dalam pemanfaatan faktor-faktor produksi (Laylah, 2019). Padahal titik impas dapat dijadikan indikator kelayakan usahatani. Analisis titik impas dapat dijadikan sebagai pengganti untuk meramalkan suatu faktor yang tidak diketahui dalam membuat keputusan usaha. Analisis ini dapat membantu menentukan aliran kas, tingkat permintaan yang dibutuhkan, serta kombinasi harga dan permintaan mana yang akan memperbesar kemungkinan untuk memperoleh keuntungan (Prasetyo, 2010).

Produksi kelapa sebagai bahan baku utama pembuatan kopra yang cukup melimpah seharusnya menjadikan keuntungan tersendiri untuk petani kopra. Akan tetapi faktanya di lapangan area pertanian yang luas serta produksi kelapa yang melimpah tidak menjadi jaminan para petani kopra memiliki pendapatan yang baik. Banyak masalah yang dihadapi oleh para petani, mulai dari rendahnya kualitas kopra yang dihasilkan oleh petani yang bukan saja mengakibatkan biaya penyusutan semakin meningkat, juga karena belum efisiennya proses produksi dan kurang memadainya kemampuan petani untuk mengelola usahatani kopra. Hal ini menunjukkan adanya resiko dalam kegiatan usaha kopra terutama resiko produksi. Resiko produksi berpengaruh terhadap produksi yang dihasilkan dan berpengaruh terhadap pendapatan usaha (Marhawati, 2019). Oleh karena itu perlu mengkaji analisis pendapatan usaha kopra di Desa Bontolempangan Kecamatan Buki Kabupaten Kepulauan Selayar.

\section{METODE PENELITIAN}

Metode penelitian yang digunakan oleh penulis adalah penelitian deskriptif kuantitatif. Teknik pengumpulan data yang digunakan yaitu observasi, dokumentasi, dan wawancara. Populasi yang terpilih dijadikan sasaran penelitian adalah semua petani kopra di Desa Bontolempangan Kecamatan Buki Kabupaten Kepulauan Selayar yang berjumlah 235 orang. Dalam penelitian ini pengambilan sampel menggunakan teknik 
simple random sampling (acak). Dari populasi sebesar 235 orang maka penarikan sampel sebesar 10\% sehingga sampel pada penelitian ini sebanyak 24 orang petani kopra.

Sumber data yang digunakan yaitu data primer dan data sekunder. Data primer diperoleh dari wawancara secara langsung dengan menggunakan kuisioner. Sedangkan data sekunder diperoleh dari berbagai studi Pustaka. Teknik analisis data yang digunakan adalah analisis pendapatan, analisis R/C ratio, dan analisis titik impas (Break Even Point).

Menurut (Satra Nugraha and Alamsyah 2019) Pendapatan adalah hasil selisih antara penerimaan usaha yang dilakukan dan biaya produksi yang dikeluarkan, dengan rumus sebagai berikut:

$$
\begin{aligned}
& I=T R-C \\
& \text { Keterangan: } \\
& \mathrm{I} \quad=\text { Income } \text { atau Pendapatan (Rp/Bulan) } \\
& \mathrm{TR}=\text { Total Revenue atau Total Penerimaan (Rp/Bulan) } \\
& \mathrm{TC}=\text { Total Cost } \text { atau Total Biaya (Rp/Bulan) }
\end{aligned}
$$

Revenue / Cost Ratio adalah merupakan perbandingan antara total penerimaan dengan total biaya, dengan rumus sebagai berikut:

Revenue cost ratio $(\mathrm{R} / \mathrm{C})=\mathrm{TR} / \mathrm{TC}$

Keterangan:

$\mathrm{R} / \mathrm{C}$ ratio $=$ Perbandingan antara penerimaan dan biaya

$\mathrm{TR}=$ Total Penerimaan / Total Revenue $(\mathrm{Rp})$

$\mathrm{TC}=$ Biaya Total $/$ Total Cost $(\mathrm{Rp})$

Keputusan:

$\mathrm{R} / \mathrm{C}$ ratio $>1$ = usaha yang dilakukan secara ekonomis efisien atau menguntungkan $\mathrm{R} / \mathrm{C}$ ratio $<1$ = Usaha yang dilakukan secara ekonomis tidak efisien atau tidak menguntungkan

$\mathrm{R} / \mathrm{C}$ ratio = 1 Berarti usaha yang dilakukan mengalami titik impas atau Break Even Point

\section{HASIL DAN PEMBAHASAN}

\section{Karakteristik Responden}

Identitas responden yang dimaksud adalah sebagian besar dari ciri-ciri yang dimiliki oleh responden serta terkait erat dengan aktivitasnya. Responden Kopra di Desa Bontolempangan Kecamatan Buki Kabupaten Kepulauan Selayar memiliki karakteristik yang berbeda-beda, berdasarkan data yang diperoleh melalui observasi dan wawancara langsung dengan responden maka karakteristik responden yang dimaksud adalah tingkat umur, tingkat pendidikan, jumlah tanggungan keluarga dan pengalaman berusaha kopra. Untuk lebih jelasnya dapat dilihat pada tabel berikut ini: 
Tabel 1. Karakteristik Petani Kelapa di Desa Bontolempangan

\begin{tabular}{clcc}
\hline Nomor & \multicolumn{1}{c}{ Uraian } & Jumlah (Orang) & Persentase (\%) \\
\hline 1. & Umur Petani & 2 & \\
& a. $30-39$ & 3 & 8,3 \\
& b. $40-49$ & 5 & 12,5 \\
& c. $50-59$ & 14 & 20,8 \\
& d. $>$ 59 & & 58,4 \\
2. & Tingkat Pendidikan & 6 & 25 \\
& Tidak tamat SD & 13 & 54,1 \\
& Tamat SD & 3 & 12,5 \\
& Tamat SMP & 2 & 8,4 \\
& Tamat SMA & & \\
3. $\quad$ Jumlah Tanggungan Keluarga & 19 & 79,1 \\
& "1 - 3" & 4 & 16,7 \\
& "4 - 6" & 1 & 4,2 \\
& $\geq 7$ & & \\
4. & Pengalaman Bertani & 10 & 41,7 \\
& " 10 - 25" & 7 & 29,2 \\
& "26 - 35" & 4 & 16,6 \\
& "36 - 45" & 3 & 12,5 \\
\hline
\end{tabular}

Sumber : Data Primer

\section{Umur Responden}

Umur seseorang sangat berpengaruh dalam berpikir dan menentukan keputusan selain itu umur juga berpengaruh terhadap kemampuan dan sikap dalam mengelolah usahatani. Pada penelitian ini, didominasi oleh petani yang telah berusia 60 sampai 75 tahun. Akan tetapi meskipun mereka telah berusia lanjut, mereka tetap bertani kelapa dan mengelolah kelapa menjadi kopra selagi mereka bisa atau mampu melakukan kegiatan usahatani yang mereka miliki. Semakin bertambahnya umur petani akan mempengaruhi pendapatan petani, karena umur akan mempengaruhi kekuatan fisik petani saat melakukan aktivitas bertani. Maka, semakin menurun kekuatan fisiknya sehingga produktvitasnya pun menurun dan pendaapatan juga ikut turun.

\section{Tingkat Pendidikan}

Tingkat pendidikan yang dimaksud adalah pendidikan formal yang diperoleh responden dibangku sekolah maupun diperguruan tinggi. tingkat pendidikan responden paling banyak hanya tamat Sekolah Dasar (SD) yaitu sebanyak 13 orang. Pada penelitian ini tingkat pendidikan yang dimiliki petani tidak terlalu berpengaruh pada pendapatan petani, karena kemampuan untuk bertani diperoleh oleh petani dari hasil membantu orang tua mereka mengelolah perkebunan kelapa. Akan tetapi, kurangnya pendidikan yang dimiliki petani menjadikan mereka sulit menerima inovasi terkait pengelolaan kelapa dengan cara yang lebih modern. Sehingga, hampir semua petani masih menggunakan cara-cara tradisional dalam memproduksi kopra. 


\section{Jumlah Tanggungan Keluarga}

Jumlah tanggungan keluarga merupakan banyaknya anggota keluarga yang masih di bawah tanggungan kepala keluarga. Jumlah tanggungan suatu keluarga akan mempengaruhi biaya yang dikeluarkan oleh kepala keluarga, karena banyaknya kebutuhan yang harus dipenuhi juga berbeda-beda. Sehingga, petani dengan jumlah tanggungan yang lebih banyak berusaha lebih keras untuk mendapatkan pendapatan yang lebih tinggi agar bisa memenuhi kebutuhan anggota keluarganya.

\section{Pengalaman Berusaha Kopra}

Yang dimaksud dengan pengalaman usahatani adalah lamanya waktu yang telah dilalui oleh petani sejak memelihara perkebunan kelapa dan mengelola kelapa menjadi menjadi kopra. Di Desa Bontolempangan, ada banyak sekali petani yang memiliki perkebunan kelapa dan mengelolahnya menjadi kopra.

Pengalaman bertani yang dimiliki petani sangat membantu dalam meningkatkan jumlah kelapa yang akan diolah menjadi kopra. Meskipun petani yang sudah berumur lebih tua mempunyai kemampuan fisik yang sudah kurang, namun mereka lebih memiliki banyak pengalaman kerja (Setiawan, 2010).. Namun, hal tersebut tidak menjamin bahwa petani yang lebih berpengalaman akan lebih sukses dibanding petani yang masih kurang pengalamannya dalam usahatani. Pada dasarnya pengalaman bertani dan mengelolah kelapa menjadi kopra diperoleh pada saat membantu Orang Tua mengelolah usahatani. Pengalaman usahatani pada penelitian ini diberi batasan yaitu sejak petani memiliki tanggungjawab penuh terhadap perkebunan kelapa yang mereka kelolah.

\section{Jumlah Produksi Kopra}

Produksi kopra yang dihasilkan dalam penelitian ini adalah jumlah produksi yang dihasilkan dalam satu kali musim panen yang dinyatakan dalam satuan kiloram ( $\mathrm{Kg}$ ). Untuk meningkatkan hasil produksi kopra petani menggunakan faktor-faktor produksi secara tepat, sehingga sesuai dengan hasil yang diharapkan

Tabel 2. Jumlah Produksi Kopra Desa Bontolempangan

\begin{tabular}{cccc}
\hline No & $\begin{array}{c}\text { Jumlah Produksi } \\
(\mathbf{K g})\end{array}$ & $\begin{array}{c}\text { Jumlah Responden } \\
\text { (Orang) }\end{array}$ & Persentase (\%) \\
\hline 1 & $<100$ & 3 & 12,5 \\
2 & $100-200$ & 8 & 33,3 \\
3 & $201-300$ & 4 & 16,7 \\
4 & $301-400$ & 3 & 12,5 \\
5 & $401-500$ & 2 & 8,3 \\
6 & $>500$ & 4 & 16,7 \\
\hline & Jumlah & 24 & 100 \\
\hline
\end{tabular}

Sumber : Data Primer 
Dari tabel 2. dapat dilihat petani paling banyak memproduksi kopra pada kisaran 100 - $200 \mathrm{Kg}$ dengan persentase 33,3\% . dan persentase yang paling kecil bearada pada kisaran $401-500 \mathrm{Kg}$ yaitu sebesar 8,3\%.

\section{Analisis Pendapatan Usaha Kopra}

Pendapatan merupakan selisih antara penerimaan dengan total biaya yang dikeluarkan selama musim panen dan merupakan masukan bagi produsen kopra untuk memenuhi kebutuhan keluarganya. Hasil penelitian menunjukkan bahwa pendapatan yang dihasilkan produsen kopra sebesar Rp. 23.786.075,- untuk satu kali produksi selama empat bulan dengan rata-rata pendapatan Rp. 1.036.333,-- Hasil analisis pendapatan usaha kopra dapat dilihat pada tabel 2 .

Berdasarkan tabel 3 terlihat bahwa total produksi yang dihasilkan usaha kopra di Desa Bontolempangan Kecamatan Buki Kabupaten Kepulauan Selayar adalah sebanyak $7.475 \mathrm{Kg} /$ satu kali produksi yaitu empat bulan dengan harga jual rata-rata Rp. 5.617/Kg sehingga total penerimaan usaha kopra sebesar Rp 41.987.075,-/ periode selama empat bulan. Adapun total biaya produksi kopra adalah sebesar Rp. 18.201.000,-- Sehingga menghasilkan pendapatan sebesar Rp 23.786.075,-/ periode selama 4 bulan dengan ratarata sebesar Rp.1.036.333,-.

Tabel 3. Pendapatan usaha kopra

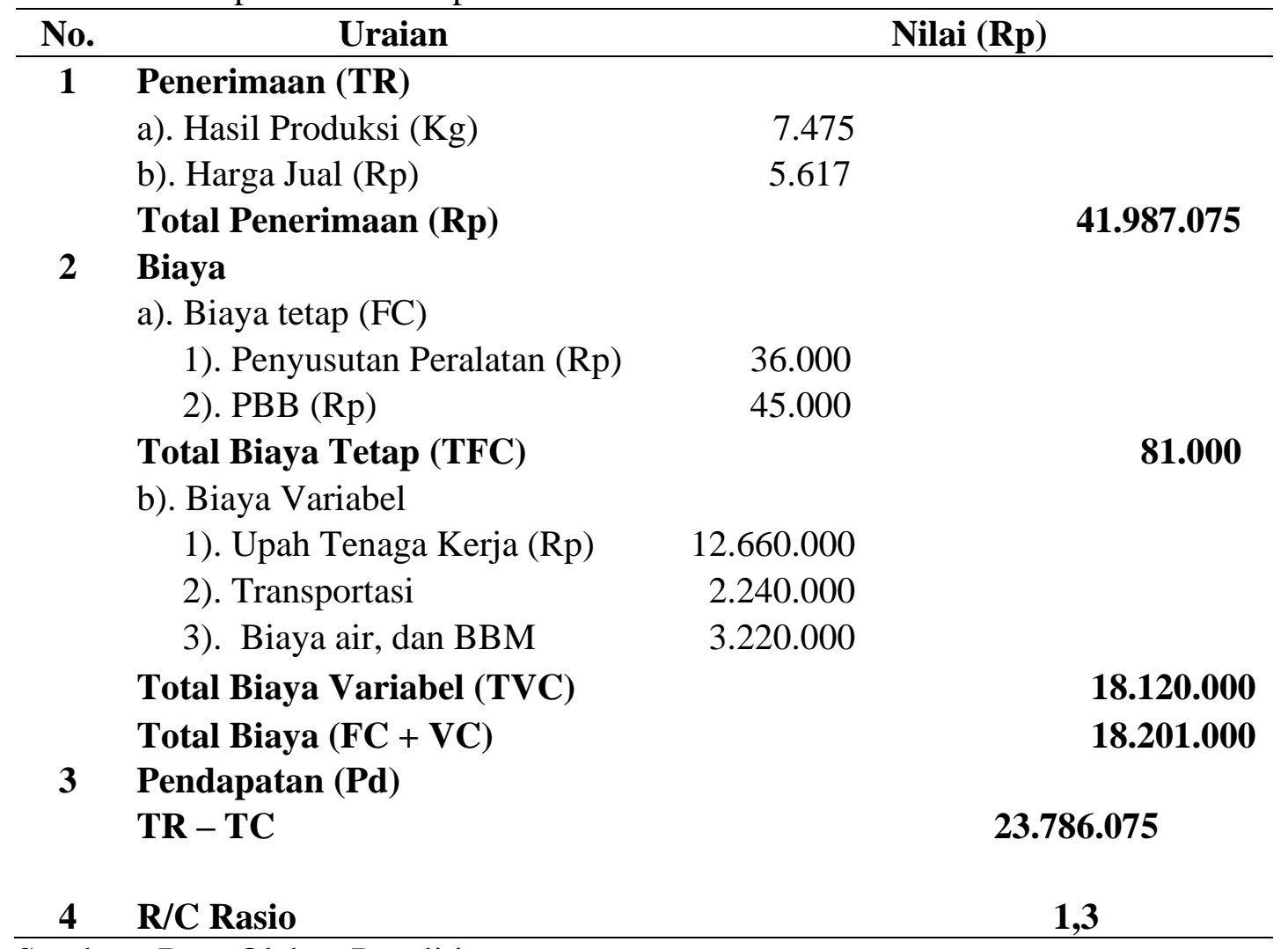

Sumber : Data Olahan Peneliti

Ada dua macam biaya yang mempengaruhi pendapatan petani kopra. Yang pertama adalah biaya tetap. Dimana biaya tetap merupakan biaya yang dikeluarkan petani 
yang jumlahnya relatif tetap dan terus dikeluarkan tanpa dipengaruhi oleh tingkat produksi kopra. Yang kedua adalah biaya tidak tetap. Untuk biaya ini biasanya dipengaruhi oleh tingkat produksi kopra.

Petani kopra dalam mengelolah usahataninya memerlukan biaya mulai dari saat pemanenan. Biaya-biaya yang dikeluarkan untuk menunjang hasil produksi usahatani, hasil produksi yang diperoleh akan dijual sehingga menghasilkan penerimaan usahatani. Penerimaan tersebut akan dikurangi dengan biaya-biaya yang telah dikeluarkan oleh petani sehingga menghasilkan pendapatan bersih usahatani kopra di Desa Bontolempangan Kecamatan Buki Kabupaten Kepulauan Selayar.

Pemasaran hasil tani kopra yang dilakukan oleh responden semuanya sama, kopra yang telah dipanen langsung diperjualbelikan oleh pengepul. Meskipun ada perbedaan harga antara responden dikarenakan waktu saat menjual hasil produksi yang tidak sama. Perbedaan harga juga disebabkan oleh tingkat kematangan kopra yang berbeda antara petani, ada beberapa petani yang mengumpulkan terlebih dulu hasil produksi sampai harga kopra lebih tinggi, sementara ada pula yang langsung menjual hasil produksinya, karena hasil jual dari kopra tersebut akan dipergunakan untuk biaya hidup dan membiayai pengeluaran untuk memproduksi kopranya.

Harga yang ditawarkan kepada petani cukup beragam, namun harga tersebut termasuk harga standar untuk petani sehingga menunjukkan usahatani kopra tetap menguntungkan dan dari 24 responden tidak ada mengalami kerugian.

\section{Analisis Kelayakan Usaha Kopra}

Analisis Break Even Point (BEP) adalah suatu keadaan yang apabila perhitungan rugi laba dari suatu periode kerja dari suatu kegiatan usaha tertentu, usahatani tidak memperoleh laba dan tidak menderita rugi (impas).

Berdasarkan gambar 1. dapat diketahui bahwa titik BEP adalah titik pertemuan antara garis total biaya dengan garis total penerimaan, terjadi pada saat produksi $24 \mathrm{Kg}$ atau penerimaan Rp. 135.000,- Kesimpulan dari pembahasan bahwa usaha kopra di Desa Bontolempangan Kecamatan Buki Kabupaten Kepulauan Selayar ditinjau dari R/C dan BEP layak untuk diusahakan. Titik impas usahatani kopra di Desa Bontolempangan Kecamatan Buki Kabupaten Kepulauan Selayar sebagai berikut:

$$
\begin{array}{rl}
\text { Dik. FC }=\text { Rp } & 81.000 \\
V C=R p & 18.120 .000 \\
S=R p & 41.987 .075 \\
\text { BEP Rupiah } & =\frac{F C}{1-\frac{V C}{S}} \\
& =\frac{81.000}{1-\frac{18.120 .000}{41.987 .075}} \\
& =\frac{81.000}{1-0,4} \\
& =\frac{81.000}{0,6} \\
& =\operatorname{Rp} .135 .000
\end{array}
$$




$$
\begin{aligned}
\mathrm{BEP} \text { Produksi } & =\frac{B E P \text { Penerimaan }(R p)}{\operatorname{Harga}} \\
& =\frac{135.000}{5.617} \\
& =24 \mathrm{Kg}
\end{aligned}
$$

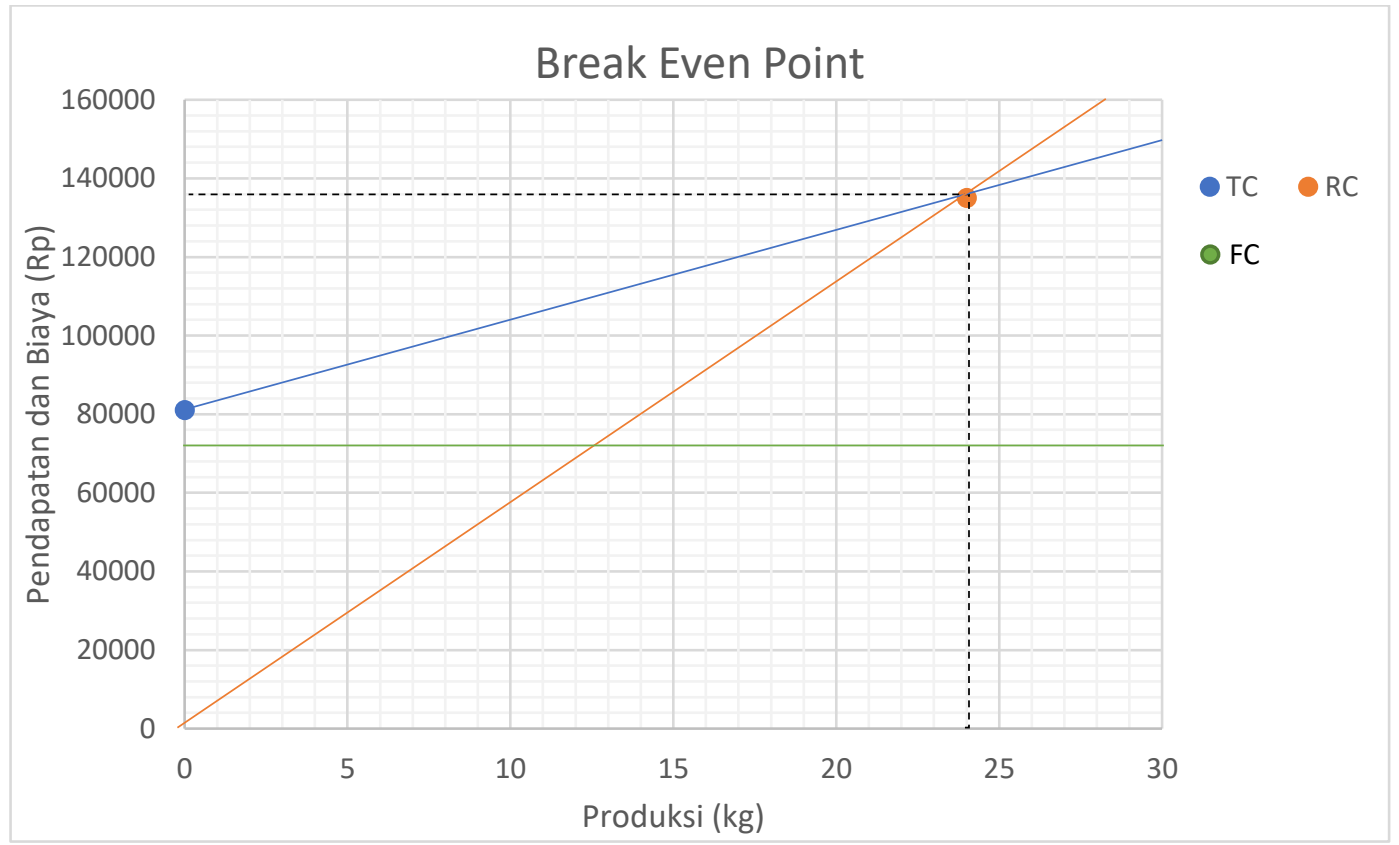

Gambar 1. Grafik Analisis Break Event Point Usaha Kopra

Kelayakan usaha kopra ditinjau dari perbandingan antara total penerimaan dan total biaya dengan rumus $\mathrm{R} / \mathrm{C}$ ratio diperoleh nilai sebesar 1.3 , yang menunjukkan bahwa usaha kopra layak untuk diusahakan karena memberikan penerimaan sebesar 1,3 dari biaya produksi yang dikeluarkan.

Melihat dari hasil penelitian kepada 24 responden di Desa Bontolempangan Kecamatan Buki Kabupaten Kepulauan Selayar yang memperoleh R/C 1,3. Dan rata-rata pendapatan sebesar Rp. 1.036.333. Ini Berarti bahwa petani memperoleh keuntungan. Akan tetapi jika dibandingkan dengan Upah Minimum Regional (UMR) provinsi Sulawesi Selatan yaitu sebesar Rp 3.103.800 berdasarkan pada keputusan Gubernur Provinsi Sulawesi Selatan. Maka pendapatan petani di Desa Bontolempangan Kecamatan Buki Kabupaten Kepulauan Selayar belum mencapai UMR yang telah ditetapkan.

\section{KESIMPULAN}

Berdasarkan hasil penelitian di Desa Bontolempangan Kecamatan Buki Kabupaten Kepulauan Selayar dengan judul Analisis Pendapatan dan Kelayakan Usaha Kopra, maka diperoleh kesimpulan bahwa usahatani kopra menguntungkan bagi petani dengan total pendapatan sebesar Rp 23.786.075,-/ periode selama empat bulan dengan rata-rata pendapatan adalah sebesar $\mathrm{Rp} 1.036 .333,-$. $\mathrm{R} / \mathrm{C}$ ratio sebesar 1,3 menunjukkan bahwa usaha kopra di Desa Bontolempangan Kecamatan Buki Kabupaten Kepulauan Selayar layak untuk diusahakan. Titik Impas atau Break Even Point (BEP) terjadi pada tingkat produksi sebanyak $24 \mathrm{Kg}$, dengan harga Rp 135.000,-- 


\section{DAFTAR PUSTAKA}

Alamsyah, A.N. (2005). Virgin Coconut Oil. Minyak Penakluk Aneka Penyakit. Penerbit Agro Media Pustaka. Jakarta.

Ditjenbun. (2018). "Statistik Perkebunan Indonesia: Kelapa (Coconut)."

Layla, Nur. (2019). "Karakteristik dan Pengaruh Faktor-faktor Produksi Terhadap Volume Hasil Produksi pada Industri Pengolahan Hasil Perkebunan di Kabupaten Kepulauan Selayar". Journal of Chemical Information and Modeling 53 (9): 168999.

Marhawati, (2019). Analisis Karakteristik dan Tingkat Pendapatan Usahatani Jeruk Pamelo Di Kabupaten Pangkep, Jurnal Ekonomi dan Pendidikan (JEKPEND) Volume 2 Nomor 2 Hal. 39-44.

Negosino. (2013). Reinventing Agribisnis Perkelapaan Nasional Ditjen Bina Produksi. Jakarta: Erlangga.

Paddilah, Sifa. (2018). "Analisis Break Even Point Sebagai Perencanaan Laba Pada Home Industri Kain Kasur Palembang Di Desa Kadu Kabupaten Tanggerang." (C):1-12.

Pangadaheng, Yanti. (2012). Analisis Pendapatan Petani Kelapa di Kecamatan Saliabu Kabupaten Talaud, Fakultas Ekonomi Universitas Sam Ratulangi Manado.

Prasetyo, Wahyudi. (2010). "Analisis Break Even Point ( BEP ) Pada Industri Pengolahan Tebu Di Pabrik Gula (PG) :" 1-99.

Satra Nugraha, Iman and Aprizal Alamsyah. (2019). "Faktor-Faktor Yang Memengaruhi Tingkat Pendapatan Petani Karet Di Desa Sako Suban, Kecamatan Batang Hari Leko, Sumatera Selatan.” Jurnal Ilmu Pertanian Indonesia 24(2):93-100.

Selayar, Badan Pusat Statistik Kabupaten Kepulauan. (2017). "Statistik Pertanian Non Tanaman Pangan Kabupaten Kepulauan Selayar 2017."

Selayar, Badan Pusat Statistik Kabupaten Kepuluan. (2019). "Kabupaten Kepulauan Selayar Dalam Angka."

Setiawan, Satrio Adi. (2010). "Pengaruh Umur, Pendidikan, Pendapatan, Pengalaman Kerja Dan Jenis Kelamin Terhadap Lama Mencari Kerja Bagi Tenaga Kerja Terdidik Di Kota Magelang." Universitas Diponegoro 1-102.

Soundakh, Joula (ed.) dkk (2015). Analisis Daya Saing Komoditas Kopra di Kabupaten Minahasa Selatan, Sulawesi Utara. Balai Pengkajian Teknologi Pertanian Sulawesi Utara16(2). 173-181

Uswa. (2017). "Pengaruh Pendapatan Masyarakat Petani Padi Terhadap Tingkat Pendidikan Anak Di Kecamatan Gantarangkeke Kabupaten Bantaeng." Fakultas Ekonomi Dan Bisnis Islam UINAM Makassar.

Wulandari, Siti Abir. (2019). "Konstribusi Pendapatan Usaha Kopra Terhadap Pendapatan Rumah Tangga Petani Di Kabupaten Tanjung Jabung Timur.” Jurnal Media Agribisnis 53(9):1689-99. 